\title{
Laboratory and Pilot-Plant Scale Photocatalytic Degradation of Polychlorinated Biphenyls in Seawater Using CM-n-TiO 2 Nanoparticles
}

\author{
Yasser A. Shaban, ${ }^{1,2}$ Mohamed A. El Sayed, ${ }^{2}$ Amr A. El Maradny, ${ }^{1,2}$ \\ Radwan Kh. Al Farawati, ${ }^{1}$ Mosa I. Al Zobidi, ${ }^{1}$ and Shahed U. M. Khan ${ }^{3}$ \\ ${ }^{1}$ Marine Chemistry Department, Faculty of Marine Sciences, King Abdulaziz University, P.O. Box 80207, \\ Jeddah 21589, Saudi Arabia \\ ${ }^{2}$ National Institute of Oceanography \& Fisheries, P.O. Box 4053, Qaitbay, Alexandria 21556, Egypt \\ ${ }^{3}$ Department of Chemistry and Biochemistry, Duquesne University, Pittsburgh, PA 15282, USA
}

Correspondence should be addressed to Yasser A. Shaban; yasrsh@yahoo.com

Received 23 January 2016; Accepted 11 April 2016

Academic Editor: Lei Zhang

Copyright (C) 2016 Yasser A. Shaban et al. This is an open access article distributed under the Creative Commons Attribution License, which permits unrestricted use, distribution, and reproduction in any medium, provided the original work is properly cited.

Photocatalytic degradation of polychlorinated biphenyls (PCBs) in seawater was successfully achieved at laboratory level with UV light and at pilot-plant scale under natural solar radiation using carbon-modified titanium oxide $\left(\mathrm{CM}-\mathrm{n}-\mathrm{TiO}_{2}\right)$ nanoparticles. The photocatalytic performance of $\mathrm{CM}-\mathrm{n}-\mathrm{TiO}_{2}$ was comparatively evaluated with reference $\mathrm{n}-\mathrm{TiO} \mathrm{O}_{2}$ under identical conditions. As a result of carbon incorporation, significant enhancement of photodegradation efficiency using $\mathrm{CM}-\mathrm{n}-\mathrm{TiO}_{2}$ was clearly observed. To optimize the operating parameters, the effects of catalyst loading and $\mathrm{pH}$ of the solution on the photodegradation rate of $\mathrm{PCBs}$ were investigated. The best degradation rate was obtained at $\mathrm{pH} 5$ and $\mathrm{CM}-\mathrm{n}-\mathrm{TiO}_{2}$ loading of $0.5 \mathrm{~g} \mathrm{~L}-1$. The photodegradation results fitted the Langmuir-Hinshelwood model and obeyed pseudo-first-order reaction kinetics.

\section{Introduction}

Polychlorinated biphenyls (PCBs) are a class of persistent organic pollutants that are ubiquitous in the environment. USEPA has classified PCBs as compounds with significant human health risk, due to their toxicity, carcinogenicity, and bioaccumulation nature [1]. Therefore, the release of these pollutants into water resources poses a serious threat to human health and the environment [2]. Though their production has been prohibited, they are still remaining in large quantities in industrial fluids, heat exchangers, and plasticizers.

Incineration is the main remediation technology for PCBs. However, it demands expensive facilities and high temperatures of more than $1200^{\circ} \mathrm{C}$ [3]. Recently, heterogeneous photocatalytic technology involving $\mathrm{TiO}_{2}$ semiconductor under light irradiation has shown potential advantages to be used as an alternative remedial technology, because it is inexpensive and can rapidly and completely mineralize organic pollutants. $\mathrm{TiO}_{2}$ has been studied extensively for practical utilization for water splitting $[4,5]$, remedy of many organic pollutants [6-9], and treatment of wastewater [1012]. However, $\mathrm{TiO}_{2}$ photocatalysis is limited to UV light, as a result of its wide bandgap $(3.0-3.2 \mathrm{eV})$. To overcome this drawback, several studies have been performed to modify $\mathrm{TiO}_{2}$ with nitrogen $[13,14]$, sulfur [15], and transition metal $[16,17]$ to extend its photoresponse to the visible region by narrowing its bandgap energy. Recently, it has been evidently demonstrated that modification of $\mathrm{TiO}_{2}$ by carbon enhanced its photoresponse by narrowing its bandgap energy [4-6]. In our previous work [9], we have successfully synthesized carbon-modified $\mathrm{TiO}_{2}$ photocatalyst with low bandgap energy of $1.8 \mathrm{eV}$. Compared to unmodified $\mathrm{TiO}_{2}$, the synthesized photocatalyst showed significantly higher activity towards the photocatalytic degradation of PCBs in aqueous solution under illumination of UV light. 
Although photocatalytic remediation of contaminated water has been extensively studied using $\mathrm{UV} / \mathrm{n}-\mathrm{TiO}_{2}$ at laboratory scale, relatively few attempts have been carried out at pilot-plant scale under natural sunlight. To the best of our knowledge, no study has been focused specifically on the photocatalytic removal of PCBs from seawater using CM-n$\mathrm{TiO}_{2}$ at solar-driven pilot-plant scale. Therefore, it could be of interest for environmental and economic considerations to evaluate the possibility of exploitation of the renewable solar energy through the utilization of pilot plant for the purification of polluted water.

In this context, this work aimed at studying the degradation efficiency of polychlorinated biphenyls (PCBs) in seawater using $\mathrm{CM}-\mathrm{n}-\mathrm{TiO}_{2}$ nanoparticles at laboratory scale under artificial UV light as well as evaluating the viability and the performance of the pilot plant for the remediation of these compounds under natural sunlight. The experimental conditions including $\mathrm{CM}-\mathrm{n}-\mathrm{TiO}_{2}$ loading and solution $\mathrm{pH}$ were optimized at the lab scale and were applied for the solar pilot plant.

\section{Materials and Methods}

2.1. Catalyst Preparation and Characterization. CM-n-TiO nanoparticles were fabricated by sonicated sol-gel method using titanium(IV) isopropoxide as a titanium and carboncontaining precursor. The preparation and characterization of $\mathrm{CM}-\mathrm{n}-\mathrm{TiO}_{2}$ have been reported in detail elsewhere [9]. Reference $\mathrm{n}-\mathrm{TiO}_{2}$ (Loba Chemie Pvt. Ltd., extra pure, India) was used for comparison.

2.2. Photocatalytic Removal Experiments. Clean seawater samples, collected from Sharm Obhur, Jeddah Red Sea coast, were spiked with various concentrations of PCBs (Aroclor 1254 and Aroclor 1260). Photocatalytic degradation experiments were performed at laboratory level with UV light and at pilot-plant scale with natural solar radiation. The effects of operating parameters including $\mathrm{CM}-\mathrm{n}-\mathrm{TiO}_{2}$ loading and $\mathrm{pH}$ of the solution on the photodegradation rate of PCBs have been investigated first at lab scale to reach the optimum conditions and then were applied at pilot-plant scale.

2.2.1. Lab Scale. For lab scale photocatalytic experiments, a $500 \mathrm{~mL}$ Pyrex glass reactor was used as a batch reactor under illumination of UV light. Both contaminated samples and the photocatalyst were loaded inside the photocatalytic reactor and continuously stirred for uniform mixing. Prior to light irradiation, the suspensions were equilibrated for $30 \mathrm{~min}$ in the dark. Then, the photoreactor was irradiated with low pressure UV fluorescent lamp (Upland, $15 \mathrm{~W}$ of wavelength $365 \mathrm{~nm}$ ) placed inside Fluorescence Cabinet (CC80 , Spectroline).

2.2.2. Pilot-Plant Scale. Solar pilot-plant scale reactor, socalled Solar Falling Film Reactor (SFFR), was designed and built. The performance of the $\mathrm{CM}-\mathrm{n}-\mathrm{TiO}_{2} / \mathrm{SFFR}$ system was evaluated towards the photocatalytic removal of PCBs under real sunlight illumination. The SFFR consists of flat tray, top

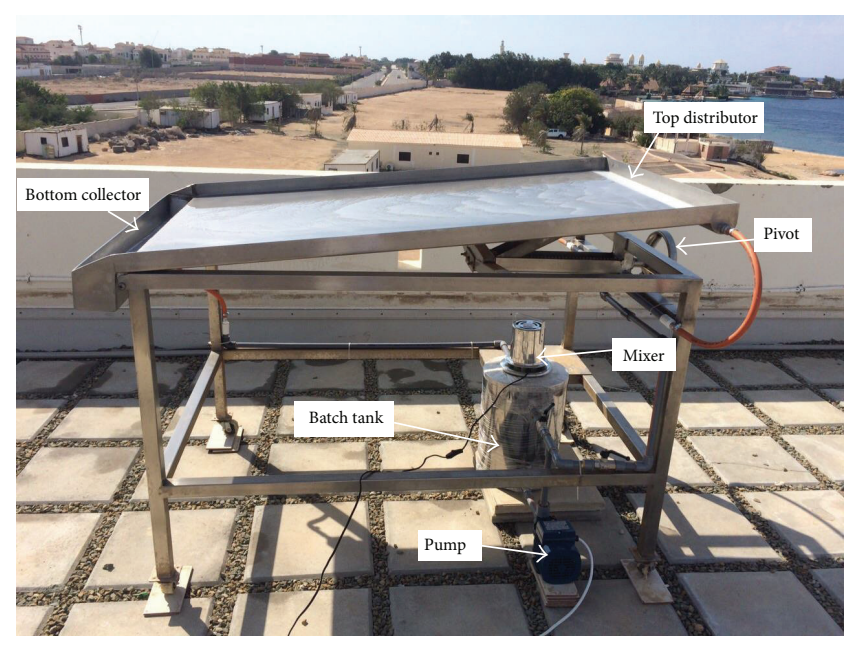

FIgURE 1: Photograph of the Solar Falling Film Reactor (SFFR).

distributor, bottom collector, a pump (Pedrollo, Italy, model: PKm 60-BR, $550 \mathrm{~W}$ ), and a batch tank (equipped with electric mixer to allow homogenization) located underneath the flat tray (Figure 1). The flat tray, top distributor, and bottom collector are made of stainless steel, Grade 316, to avoid rust problems that may affect the measurements. The flat tray is about $1.0 \mathrm{~m}$ wide by $1.5 \mathrm{~m}$ length with $10 \mathrm{~cm}$ side height. The fluid flows from the tank using the pump to the top distributor of the SFFR down to the flat tray to the bottom collector and back to the tank again; the water thus continuously circulates in a closed circuit. The flow rate is adjusted by a by-pass valve. The flat tray is mounted on a stainless steel stand with pivot allowing accurate adjustment of the tilt angle; the tilt angle was adjusted to be $22^{\circ} \pm 10^{\circ}$ for maximum solar collection in Jeddah. The SFFR has an irradiated surface of $1.5 \mathrm{~m}^{2}$ and total volume of $20 \mathrm{~L}$. The experiments were carried out on sunny days between 11:00 a.m. and 3:00 p.m. The average solar intensity was $1140 \mathrm{Wm}^{-2}$, measured by Field Scout Light Sensor Reader (Spectrum Technologies, Inc.) equipped with 3670i Silicon Pyranometer Sensor.

2.3. Analysis. Treated PCBs solution was sampled at regular irradiation intervals. The samples containing photocatalyst were centrifuged for 5 minutes and then the supernatant was shaken with $2 \mathrm{~mL}$ of a mixture of hexane and dichloromethane $(1: 1)$ for $15 \mathrm{~min}$. Using a nitrogen evaporator, extracted samples were concentrated to $0.5 \mathrm{~mL}$ and then transferred to screw capped vials and stored at $4^{\circ} \mathrm{C}$ before analysis. The concentration of PCBs (Ar 1254 and Ar 1260) was measured using gas chromatograph coupled with ${ }^{63} \mathrm{Ni}$ electron capture detector (GC-ECD, Shimadzu 2010). RxiXLB capillary column $(30 \mathrm{~m} \times 0.32 \mathrm{~mm} \times 0.5 \mu \mathrm{m})$ was used. The injection port temperature was held at $250^{\circ} \mathrm{C}$ and the detector temperature was kept at $320^{\circ} \mathrm{C}$. A constant flow rate of $1.7 \mathrm{~mL} / \mathrm{min}$ was applied for carrier gas. The volume of $2.0 \mu \mathrm{L}$ was used for injection. The temperature of the oven was held at $100^{\circ} \mathrm{C}$ for $1 \mathrm{~min}$, ramped up to $270^{\circ} \mathrm{C}$ at rate of $30^{\circ} \mathrm{C} / \mathrm{min}$, and maintained for $1 \mathrm{~min}$ and finally ramped up to $300^{\circ} \mathrm{C}$ at rate of $2.0^{\circ} \mathrm{C} / \mathrm{min}$ and kept for $3 \mathrm{~min}$. The PCBs 
TABLE 1: Optical properties of $\mathrm{CM}-\mathrm{n}-\mathrm{TiO}_{2}$ and $\mathrm{n}-\mathrm{TiO}_{2}$ nanoparticles.

\begin{tabular}{|c|c|c|c|c|c|c|}
\hline \multirow{2}{*}{ Catalyst } & \multirow{2}{*}{ Crystal phase } & \multirow{2}{*}{ Crystalline size (nm) } & \multirow{2}{*}{ Bandgap (eV) } & \multicolumn{3}{|c|}{ Atomic \% } \\
\hline & & & & $\mathrm{Ti}$ & $\mathrm{O}$ & $\mathrm{C}$ \\
\hline CM-n-TiO & Anatase & 31.4 & 1.8 & 29.81 & 61.21 & 8.98 \\
\hline $\mathrm{n}-\mathrm{TiO}_{2}$ & Anatase & 41.5 & 2.99 & 36.54 & 63.46 & 00.00 \\
\hline
\end{tabular}

were identified by comparison of retention time using series of PCBs standards. The removal efficiency $(R \%)$ is calculated as follows:

$$
R \%=\frac{A_{0}-A_{t}}{A_{0}} \times 100,
$$

where $A_{0}$ and $A_{t}$ are the peak areas of PCBs before (i.e., at zero time) and after irradiation at $(t)$ time, respectively.

\section{Results and Discussion}

3.1. Photocatalyst Characterization. In our previous work [9], carbon-modified titanium oxide $\left(\mathrm{CM}-\mathrm{n}-\mathrm{TiO}_{2}\right)$ and unmodified titanium dioxide $\left(\mathrm{n}-\mathrm{TiO}_{2}\right)$ nanoparticles were characterized in detail. Table 1 summarizes the optical properties of each catalyst. As can be seen, the incorporation of carbon (8.98 atomic \%) into $\mathrm{CM}-\mathrm{n}-\mathrm{TiO}_{2}$ lowered the bandgap energy from 2.99 to $1.8 \mathrm{eV}$. Therefore, it is expected that $\mathrm{CM}-\mathrm{n}-\mathrm{TiO}_{2}$ will have higher photocatalytic activity than $n-\mathrm{TiO}_{2}$ in both UV and visible regions.

\subsection{Photocatalytic Degradation at Laboratory Scale}

3.2.1. Effect of Catalyst Loading. The effect of $\mathrm{CM}-\mathrm{n}-\mathrm{TiO}_{2}$ dose on the photocatalytic degradation of a mixture of $\mathrm{Ar}$ $1254(0.5 \mathrm{ppm})$ and $\operatorname{Ar} 1260(0.5 \mathrm{ppm})$ in seawater under illumination of UV light was studied to attain the optimum catalyst loading (Figure 2). It is clearly noted that the increase in the amount of catalyst from $0.25 \mathrm{~g} \mathrm{~L}^{-1}$ to $0.5 \mathrm{~g} \mathrm{~L}^{-1}$ increases the photocatalytic degradation rate due to the increase of the number of hydroxyl radicals. Further increase in the catalyst loading leads to the reduction of the degradation rate, revealing optimum catalyst loading of $0.5 \mathrm{~g} / \mathrm{L}$. The observed decrease in degradation rate can be attributed to the agglomeration of catalyst particles in addition to the light shading by the suspension $[18,19]$.

3.2.2. Effect of $p H$. The effect of $\mathrm{pH}$ on the photodegradation of PCBs in seawater under illumination of UV using CM-n$\mathrm{TiO}_{2}$ was studied at three different $\mathrm{pH}$ values 5, 7, and 9. As clearly shown in Figure 3, the rate of the photodegradation process of PCBs is dependent on the $\mathrm{pH}$ values. When the $\mathrm{pH}$ value was 5, a rapid degradation process for PCBs with the highest degradation rate $\left(0.3742 \mathrm{~min}^{-1}\right)$ was obtained. This value is 2.26 times higher than that obtained at $\mathrm{pH} 9$. Generally, the mechanism of the photocatalytic degradation reaction using $\mathrm{TiO}_{2}$ as a photocatalyst depends on the adsorption between the target compound and the photocatalyst. The extent of such adsorption depends on the charge of the degraded compound as well as the catalyst, which in

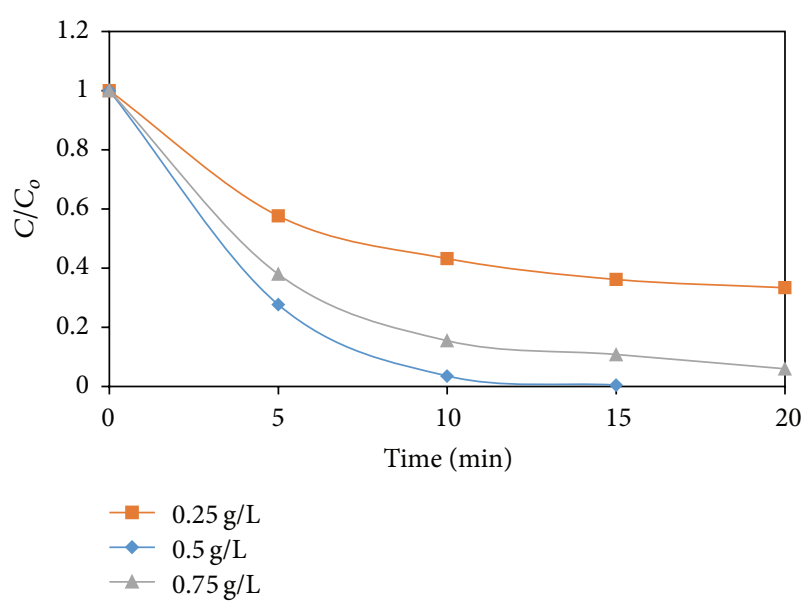

Figure 2: Effect of catalyst dose on the photocatalytic degradation of mixture of Ar 1254 (0.5 ppm) and Ar 1260 (0.5 ppm) in seawater under illumination of UV light.

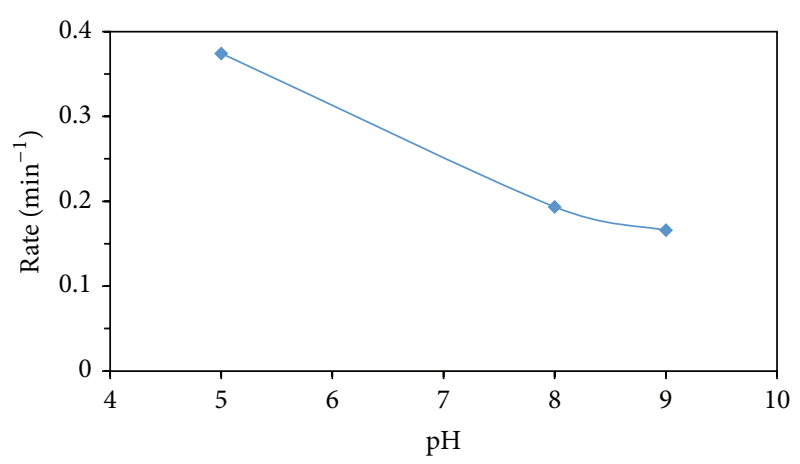

FIgURE 3: Effect of $\mathrm{pH}$ on the photocatalytic degradation of mixture of $\operatorname{Ar} 1254(0.5 \mathrm{ppm})$ and $\operatorname{Ar} 1260$ (0.5 ppm) in seawater using $0.5 \mathrm{~g} \mathrm{~L}^{-1}$ of $\mathrm{CM}-\mathrm{n}-\mathrm{TiO}_{2}$ under illumination of UV light.

turn depends on the $\mathrm{pH}$ of a given solution. At $\mathrm{pH}$ value lower than the point of zero charge $\left(\mathrm{pH}_{\mathrm{pzc}}\right)$ of $\mathrm{TiO}_{2}$, positively charged $\mathrm{TiO}_{2}$ surface with the species $\mathrm{TiOH}_{2}{ }^{+}$exists, while the PCBs and intermediates are negatively charged naturally. Consequently, the adsorption of PCBs is favorable at low $\mathrm{pH}$ due to the electrostatic attraction. Furthermore, formation of carbonate ions, which are effective scavengers of hydroxyl radical $\left({ }^{\circ} \mathrm{OH}\right)$, is favorable at high $\mathrm{pH}$ values; as a result, reduction of the degradation efficiency was observed.

3.2.3. Photocatalytic Activity of $n-\mathrm{TiO}_{2}$ and $\mathrm{CM}-n-\mathrm{TiO}_{2}$. In order to examine the photocatalytic efficiency of CM-n-TiO comparison with unmodified $\mathrm{n}-\mathrm{TiO}_{2}$ was performed under 


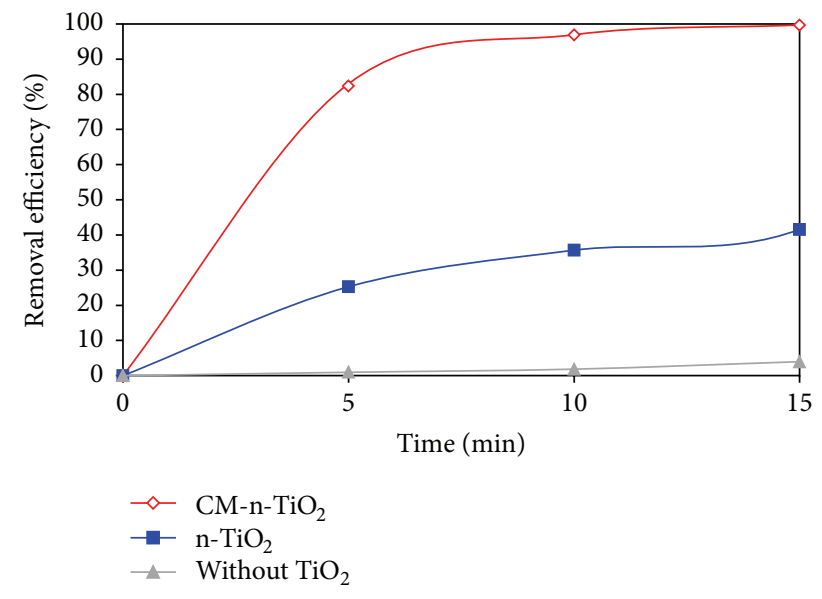

FIgURE 4: Photocatalytic degradation of a mixture of Ar 1254 $(0.5 \mathrm{ppm})$ and $\mathrm{Ar} 1260$ (0.5 ppm) in seawater using n- $\mathrm{TiO}_{2}$ and CM$\mathrm{n}-\mathrm{TiO}_{2}$ under illumination of UV light.

the same optimum experimental conditions (Figure 4). No degradation was obtained in the absence of the photocatalyst (i.e., under photolysis conditions). The photocatalytic efficiency of CM-n- $\mathrm{TiO}_{2}\left(0.5 \mathrm{~g} \mathrm{~L}^{-1}\right)$ towards the photocatalytic degradation of mixture of Ar 1254 (0.5 ppm) and Ar 1260 $(0.5 \mathrm{ppm})$ in seawater at the optimum $\mathrm{pH} 5$ under illumination of UV light is much higher than that of $\mathrm{n}-\mathrm{TiO}_{2}$. Complete degradation of PCBs was achieved after 15 min of UV light illumination. On the other hand, when the reference $\mathrm{TiO}_{2}$ was used, only $45.92 \%$ of the same concentration of PCBs was removed after the same irradiation period. The remarkable enhancement in the photocatalytic activity of $\mathrm{CM}-\mathrm{n}-\mathrm{TiO}_{2}$ nanoparticles can be attributed to the narrowing of the optical bandgap energy from $2.99 \mathrm{eV}$ for $\mathrm{n}-\mathrm{TiO}_{2}$ to $1.8 \mathrm{eV}$ for CM-n$\mathrm{TiO}_{2}$ as a result of the carbon modification of $\mathrm{TiO}_{2}[4-6,9]$. The significant narrowing of the optical bandgap energy of $\mathrm{CM}-\mathrm{n}-\mathrm{TiO}_{2}$ can be ascribed to the mixing of $\mathrm{C} 2 \mathrm{p}$ with the $\mathrm{O}$ $2 p$ valence bands [20] as a result of the carbon modification of titanium oxide. The observed optical behavior of the low bandgap energy for the synthesized CM-n-TiO ${ }_{2}$ is in good agreement with the previously reported $E_{g}$ values of $2.35 \mathrm{eV}$ [4], $1.45 \mathrm{eV}$ [5], and $1.86 \mathrm{eV}$ [6]. Furthermore, theoretical studies by Di Valentin et al. [21] addressed the notion that the presence of interstitial and substitutional carbon dopants incorporated into $\mathrm{TiO}_{2}$ drastically lowered its bandgap. Nie and Sohlberg [22] obtained low bandgap value of $2.32 \mathrm{eV}$ by incorporation of carbon into $\mathrm{n}-\mathrm{TiO}_{2}$ and predicted the possibility of achieving low bandgap of $1.58 \mathrm{eV}$ by some complex carbon incorporation.

3.3. Photocatalytic Degradation at Pilot-Plant Scale. To evaluate the viability and the performance of the solar pilot plant (SFFR), the photocatalytic degradation of PCBs (1.0 ppm) in seawater was examined at the optimal conditions, obtained from laboratory scale experiments, of $\mathrm{pH} 5$ and $0.5 \mathrm{~g} \mathrm{~L}^{-1}$ of $\mathrm{CM}-\mathrm{n}-\mathrm{TiO}_{2}$ (Figure 5). Complete degradation of PCBs was achieved after 15 and 75 min of irradiation under UV (lab scale) and sunlight (pilot plant), respectively. It is clearly

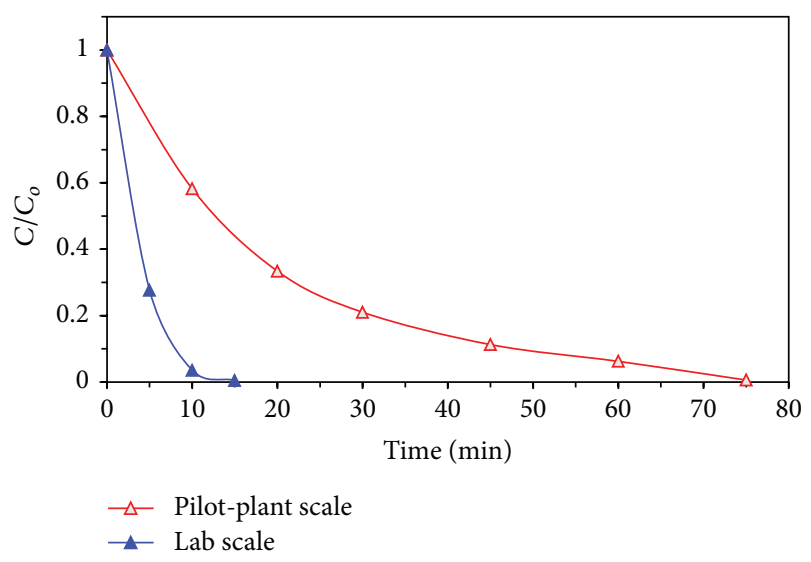

FIgure 5: Photocatalytic degradation of PCBs (1.0 ppm) in seawater using $\mathrm{CM}-\mathrm{n}-\mathrm{TiO}_{2}$ at lab scale and pilot-plant scale.

noted that the remediation of PCBs at lab scale under UV light for $500 \mathrm{~mL}$ sample was successfully extrapolated to a larger pilot-plant system for $20 \mathrm{~L}$ of polluted seawater under illumination of real sunlight.

On the other hand, a comparison with regular $\mathrm{n}-\mathrm{TiO}_{2}$ was performed under the same experimental conditions in order to assess the photocatalytic performance of CM-n$\mathrm{TiO}_{2}$ in the SFFR for the degradation of $\operatorname{Ar} 1254$ (0.5 ppm), Ar 1260 (0.5 ppm), and a mixture of Ar 1254 (0.5 ppm) and $\operatorname{Ar} 1260(0.5 \mathrm{ppm})$. As a result of carbon incorporation, remarkably higher photodegradation efficiency of CM-n$\mathrm{TiO}_{2}$ is clearly noted, reflecting the capability of CM-n-TiO to harvest maximum solar light photons and hence enhance the degradation efficiency. After $60 \mathrm{~min}$ of solar irradiation, PCBs were easily degraded with efficiencies of $92.1 \%$ for $\mathrm{Ar}$ 1254 (Figure 6(a)), 94.6\% for Ar 1260 (Figure 6(b)), and 93.7\% for the mixture of Ar 1254 and Ar 1260 (Figure 6(c)).

3.4. Kinetic Studies. To depict the kinetics of photocatalytic reactions of aqueous organics, the Langmuir-Hinshelwood (L-H) model was employed [23-25]. According to this model, the relationship between the degradation rate $(r)$ and concentration of the reactant in water at time $t(C)$ can be expressed as follows:

$$
r=-\frac{d c}{d t}=\frac{k_{r} K_{\mathrm{ad}}}{1+K_{\mathrm{ad}} C}
$$

where the constants $k_{r}$ and $K_{\text {ad }}$ represent the rate and the adsorption equilibrium, respectively. This equation can be simplified to represent the pseudo-first-order reaction when $C_{o}$ is very small as follows:

$$
\ln \left(\frac{C_{o}}{C}\right)=k_{r} K_{\mathrm{ad}} t=k_{\mathrm{app}} t
$$

where $k_{\text {app }}$ and $C_{o}$ are the apparent first-order rate constant and the concentration at zero time, respectively. The half-life time reaction $\left(t_{1 / 2}\right)$, the amount of time required for $50 \%$ of 
TABLE 2: Apparent rate constants $\left(k_{\text {app }}\right)$ and half-life time reaction $\left(t_{1 / 2}\right)$ for the photocatalytic degradation of PCBs in seawater using the pilot plant (SFFR).

\begin{tabular}{|c|c|c|c|c|c|c|}
\hline \multirow{2}{*}{ PCBs } & \multicolumn{3}{|c|}{$\mathrm{CM}-\mathrm{n}-\mathrm{TiO}_{2}$} & \multicolumn{3}{|c|}{$\mathrm{n}-\mathrm{TiO}_{2}$} \\
\hline & $k_{\text {app }}\left(\min ^{-1}\right)$ & $t_{1 / 2}(\min )$ & $R^{2}$ & $k_{\text {app }}\left(\min ^{-1}\right)$ & $t_{1 / 2}(\min )$ & $R^{2}$ \\
\hline Ar 1254 (0.5 ppm) & 0.0416 & 16.66 & 0.9854 & 0.0218 & 31.80 & 0.9759 \\
\hline $\operatorname{Ar} 1260$ (0.5 ppm) & 0.0509 & 13.62 & 0.9818 & 0.0231 & 30.01 & 0.985 \\
\hline $\operatorname{Ar} 1254(0.5 \mathrm{ppm})+\operatorname{Ar} 1260(0.5 \mathrm{ppm})$ & 0.0482 & 14.38 & 0.9909 & 0.0225 & 30.81 & 0.9983 \\
\hline
\end{tabular}

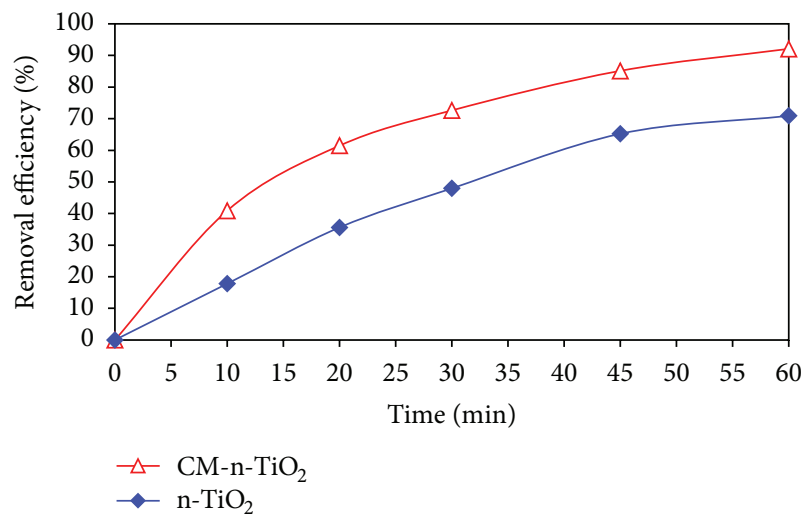

(a)

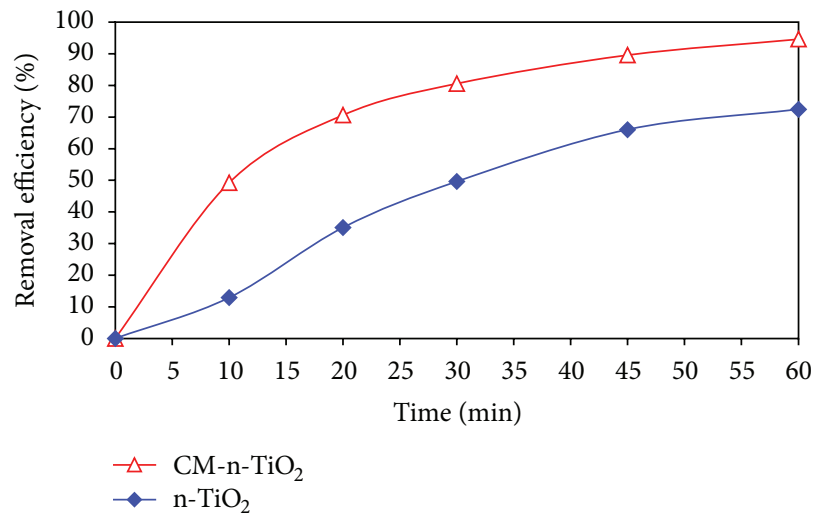

(b)

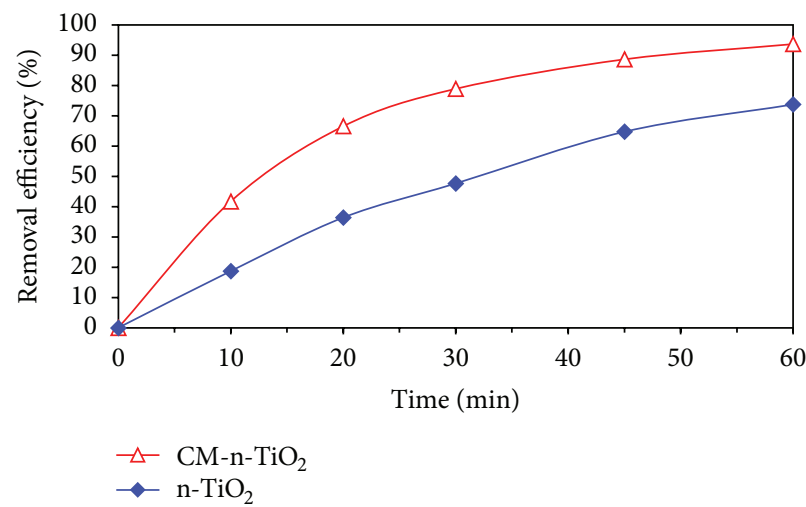

(c)

Figure 6: Photocatalytic degradation of (a) Ar 1254 (0.5 ppm), (b) Ar 1260 (0.5 ppm), and (c) mixture of Ar 1254 (0.5 ppm) and Ar 1260 $(0.5 \mathrm{ppm})$ in seawater at the optimal conditions of $\mathrm{pH} 5$ and $0.5 \mathrm{~g} \mathrm{~L}^{-1}$ of the photocatalyst $\left(\mathrm{n}-\mathrm{TiO}_{2}\right.$ and $\left.\mathrm{CM}-\mathrm{n}-\mathrm{TiO}_{2}\right)$ under illumination of natural sunlight using the pilot plant (SFFR).

the initial concentration to disappear, can be calculated as follows:

$$
t_{1 / 2}=\frac{\ln (2)}{k_{\mathrm{app}}} .
$$

By plotting $\ln \left(C_{o} / C\right)$ versus irradiation time $(t)$, a linear behavior that indicates pseudo-first-order kinetics for the photocatalytic degradation of PCBs was obtained (Figure 7). From the apparent rate constant, calculated from the slope of the linear plot, and $t_{1 / 2}$ values (Table 2 ), it is interesting to note that the solar photocatalytic degradation of PCBs using the pilot plant (SFFR) in the presence of CM-n-TiO 2 is twofold faster in comparison with that of regular $\mathrm{TiO}_{2}$, confirming the potentiality of CM-n- $\mathrm{TiO}_{2} /$ SFFR as an efficient system for the photocatalytic degradation of PCBs in seawater.

\section{Conclusions}

Unique carbon-modified titanium oxide $\left(\mathrm{CM}-\mathrm{n}-\mathrm{TiO}_{2}\right)$ nanoparticles were successfully fabricated via sonicated sol-gel method using titanium(IV) isopropoxide as Ti and a carboncontaining precursor. Comparative evaluation of the photocatalytic performance of carbon-modified and regular titanium oxide towards the photocatalytic removal of PCBs was performed. The bandgap energy has been reduced from $2.99 \mathrm{eV}$ for $\mathrm{n}-\mathrm{TiO}_{2}$ to $1.8 \mathrm{eV}$ for $\mathrm{CM}-\mathrm{n}-\mathrm{TiO}_{2}$, which in turn improved the photocatalytic performance of $\mathrm{CM}-\mathrm{n}-\mathrm{TiO}_{2}$ by absorption of more light photons. The results showed that the removal rate of PCBs was favorable at catalyst dosage of $0.5 \mathrm{gL}^{-1}$ and $\mathrm{pH}$ 5. The photodegradation kinetics of PCBs using $\mathrm{CM}-\mathrm{n}-\mathrm{TiO}_{2}$ followed a pseudo-first-order reaction. 


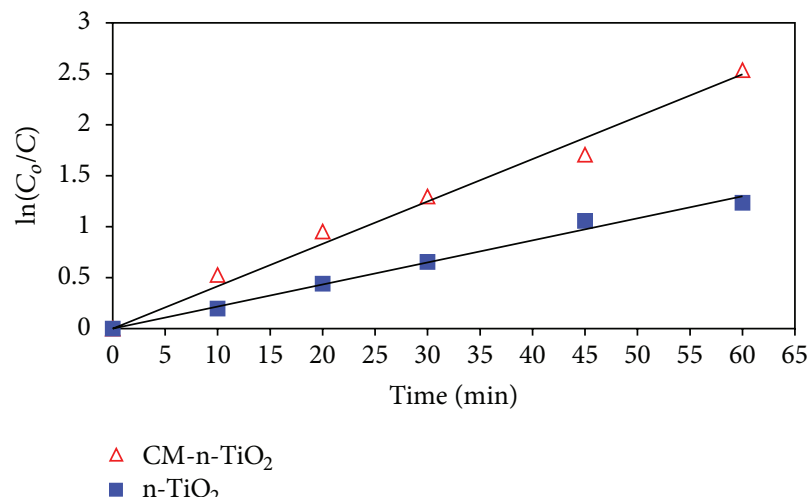

(a)

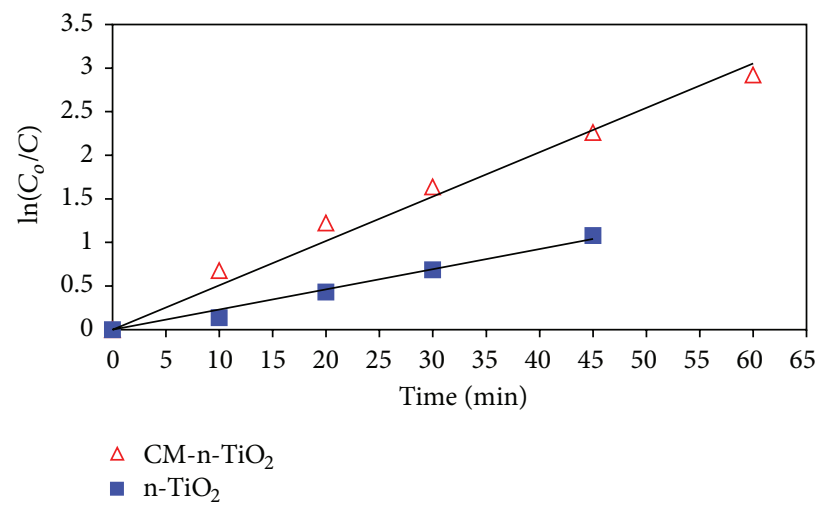

(b)

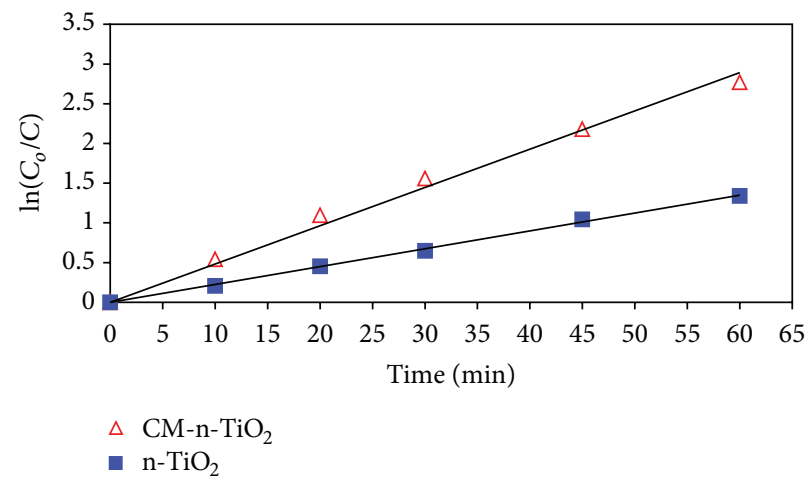

(c)

Figure 7: Kinetic analysis for the photocatalytic degradation of (a) Ar 1254 (0.5 ppm), (b) Ar 1260 (0.5 ppm), and (c) mixture of Ar 1254 (0.5 ppm) and Ar 1260 (0.5 ppm) in seawater using the pilot plant (SFFR).

The photocatalytic degradation of PCBs in seawater has been successfully achieved using $\mathrm{CM}-\mathrm{n}-\mathrm{TiO}_{2}$ nanoparticles at laboratory level with UV light and at pilot-plant scale (SFFR) under natural solar radiation. Furthermore, the results obtained evidenced the validity of CM-n-TiO $/$ SFFR system as an attractive and promising technique for the remediation of polluted water.

\section{Competing Interests}

The authors declare that they have no competing interests.

\section{Acknowledgments}

This project was funded by the National Plan for Science, Technology and Innovation (MAARIFAH), King Abdulaziz City for Science and Technology, Kingdom of Saudi Arabia, Award no. 12-NAN2241-03. The authors also acknowledge with thanks the Science and Technology Unit, King Abdulaziz University, for technical support. The authors are thankful to Mr. Kazem Sultan and Mr. Yasar N. K. for their appreciable help in the experimental analysis.

\section{References}

[1] United States Environmental Protection Agency, "National air toxics information report: qualitative and quantitative carcinogenic risk assessment," EPA 450/5-87-003, US Environmental Protection Agency and STAPPA/ALAPCO, Washington, DC, USA, 1987.

[2] E. H. Buckley, "Accumulation of airborne polychlorinated biphenyls in foliage," Science, vol. 216, no. 4545, pp. 520-522, 1982.

[3] M. L. Hitchman, R. A. Spackman, N. C. Ross, and C. Agra, "Disposal methods for chlorinated aromatic waste," Chemical Society Reviews, vol. 24, no. 6, pp. 423-430, 1995.

[4] S. U. M. Khan, M. Al-Shahry, and W. B. Ingler Jr., "Efficient photochemical water splitting by a chemically modified n$\mathrm{TiO}_{2}$," Science, vol. 297, no. 5590, pp. 2243-2245, 2002.

[5] Y. A. Shaban and S. U. M. Khan, "Photoresponse of visible light active CM-n-TiO $, 4 M-n-\mathrm{TiO}_{2}, \mathrm{CM}-\mathrm{n}-\mathrm{Fe}_{2} \mathrm{O}_{3}$, and CM$\mathrm{p}-\mathrm{WO}_{3}$ towards water splitting reaction," International Journal of Photoenergy, vol. 2012, Article ID 749135, 20 pages, 2012.

[6] Y. A. Shaban, M. A. El Sayed, A. A. El Maradny, R. K. Al Farawati, and M. I. Al Zobidi, "Photocatalytic degradation of phenol in natural seawater using visible light active carbon modified (CM)-n- $\mathrm{TiO}_{2}$ nanoparticles under UV light and 
natural sunlight illuminations," Chemosphere, vol. 91, no. 3, pp. 307-313, 2013.

[7] H. Park and W. Choi, "Photocatalytic reactivities of nafioncoated $\mathrm{TiO}_{2}$ for the degradation of charged organic compounds under UV or visible light," Journal of Physical Chemistry B, vol. 109, no. 23, pp. 11667-11674, 2005.

[8] C. Xu, R. Killmeyer, M. L. Gray, and S. U. M. Khan, "Photocatalytic effect of carbon-modified $\mathrm{n}-\mathrm{TiO}_{2}$ nanoparticles under visible light illumination," Applied Catalysis B: Environmental, vol. 64, no. 3-4, pp. 312-317, 2006.

[9] Y. A. Shaban, M. A. El Sayed, A. A. El Maradny, R. K. Al Farawati, M. I. Al Zobidi, and S. U. M. Khan, "Photocatalytic removal of polychlorinated biphenyls (PCBs) using carbonmodified titanium oxide nanoparticles," Applied Surface Science, vol. 365, pp. 108-113, 2016.

[10] K. Yamaguti and S. J. Sato, "Photolysis of water over metallized powdered titanium dioxide," Journal of the Chemical Society, Faraday Transactions 1: Physical Chemistry in Condensed Phases, vol. 81, no. 5, pp. 1237-1246, 1985.

[11] T. Oppenlander, Photochemical Purification of Water and Air, Wiley-VCH, Weinheim, Germany, 2003.

[12] S. Parsons, Advanced Oxidation Processes for Water and Wastewater Treatment, IWA Publishing, Cornwall, UK, 2004.

[13] C. Burda, Y. Lou, X. Chen, A. C. S. Samia, J. Stout, and J. L. Gole, "Enhanced nitrogen doping in $\mathrm{TiO}_{2}$ nanoparticles," Nano Letters, vol. 3, no. 8, pp. 1049-1051, 2003.

[14] R. Asahi, T. Morikawa, T. Ohwaki, K. Aoki, and Y. Taga, "Visible-light photocatalysis in nitrogen-doped titanium oxides," Science, vol. 293, no. 5528, pp. 269-271, 2001.

[15] T. Umebayashi, T. Yamaki, H. Itoh, and K. Asai, "Band gap narrowing of titanium dioxide by sulfur doping," Applied Physics Letters, vol. 81, no. 3, pp. 454-456, 2002.

[16] W. Choi, A. Termin, and M. R. Hoffmann, "The role of metal ion dopants in quantum-sized $\mathrm{TiO}_{2}$ : correlation between photoreactivity and charge carrier recombination dynamics," Journal of Physical Chemistry, vol. 98, no. 51, pp. 13669-13679, 1994.

[17] M. Anpo, "Photocatalysis on titanium oxide catalysts-approaches in achieving highly efficient reactions and realizing the use of visible light," Catalysis Surveys from Japan, vol. 1, no. 2, pp. 169-179, 1997.

[18] R. R. Wang, D. Ren, S. Xia, Y. Zhang, and J. Zhao, "Photocatalytic degradation of Bisphenol A (BPA) using immobilized $\mathrm{TiO}_{2}$ and UV illumination in a horizontal circulating bed photocatalytic reactor (HCBPR)," Journal of Hazardous Materials, vol. 169, no. 1-3, pp. 926-932, 2009.

[19] S. Merabet, A. Bouzaza, and D. Wolbert, "Photocatalytic degradation of indole in a circulating upflow reactor by $\mathrm{UV} / \mathrm{TiO}_{2}$ process-Influence of some operating parameters," Journal of Hazardous Materials, vol. 166, no. 2-3, pp. 1244-1249, 2009.

[20] Y. Nakano, T. Morikawa, T. Ohwaki, and Y. Taga, "Electrical characterization of band gap states in C-doped $\mathrm{TiO}_{2}$ films," Applied Physics Letters, vol. 87, no. 5, Article ID 052111, 2005.

[21] C. Di Valentin, G. Pacchioni, and A. Selloni, "Theory of carbon doping of titanium dioxide," Chemistry of Materials, vol. 17, no. 26, pp. 6656-6665, 2005.

[22] X. Nie and K. Sohlberg, "The influence of surface reconstruction and C-impurities on photocatalytic water dissociation by $\mathrm{TiO}_{2}$," in Materials Research Society Symposium Proceedings on Materials and Technology for Hydrogen Economy, G.-A. Nazri et al., Ed., vol. 801 of MRS Proceedings, p. 205, Boston, Mass, USA, December 2003.
[23] A. V. Petukhov, "Effect of molecular mobility on kinetics of an electrochemical Langmuir-Hinshelwood reaction," Chemical Physics Letters, vol. 277, no. 5-6, pp. 539-544, 1997.

[24] B. Bayarri, J. Giménez, D. Curcó, and S. Esplugas, "Photocatalytic degradation of 2,4-dichlorophenol by $\mathrm{TiO}_{2} / \mathrm{UV}$ : kinetics, actinometries and models," Catalysis Today, vol. 101, no. 3-4, pp. 227-236, 2005.

[25] E. E. Kusvuran, A. Samil, O. M. Atanur, and O. Erbatur, "Photocatalytic degradation kinetics of di- and tri-substituted phenolic compounds in aqueous solution by $\mathrm{TiO}_{2} / \mathrm{UV}$," Applied Catalysis B: Environmental, vol. 58, no. 3-4, pp. 211-216, 2005. 

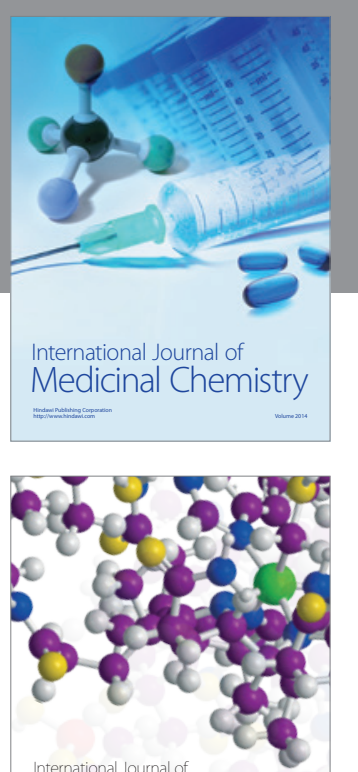

Carbohydrate Chemistry

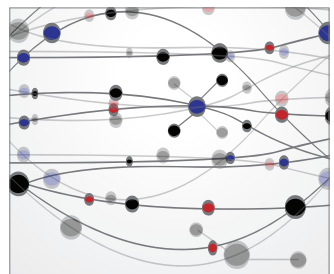

The Scientific World Journal
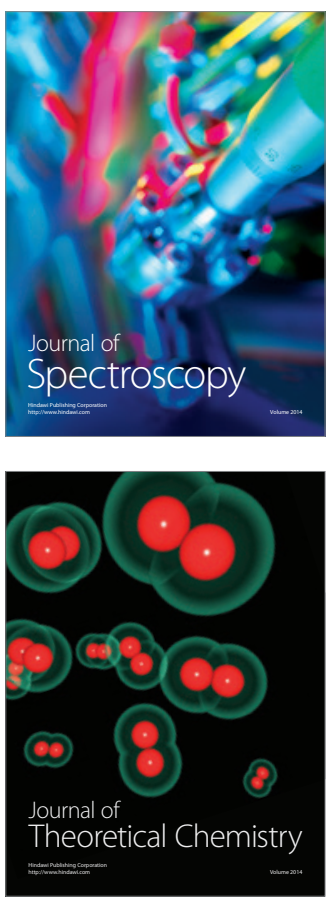
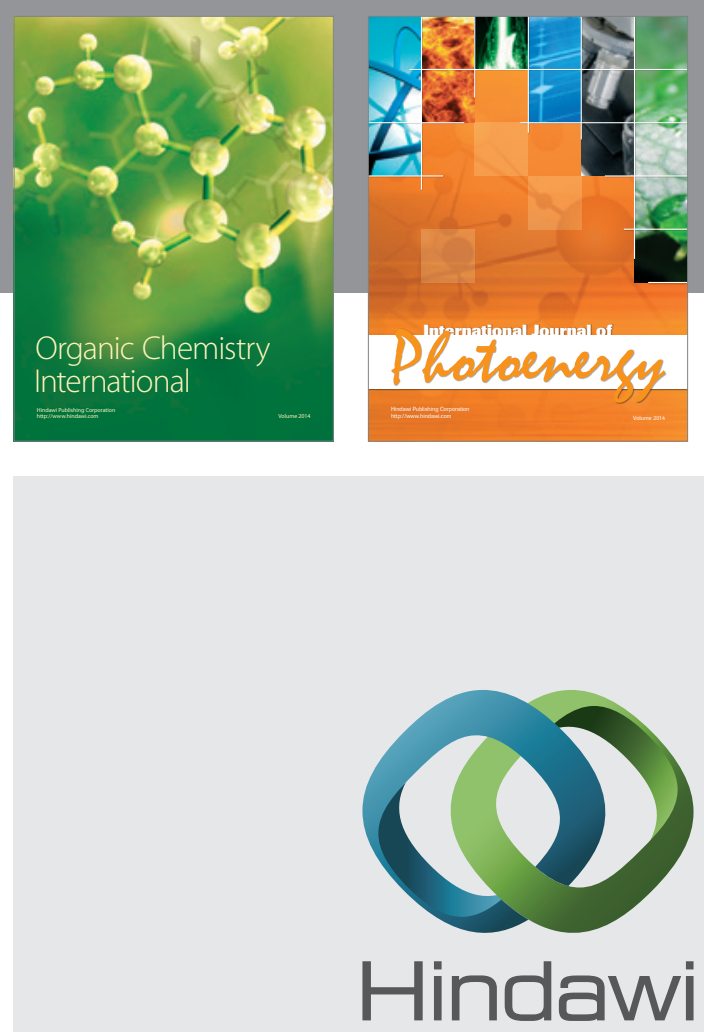

Submit your manuscripts at

http://www.hindawi.com

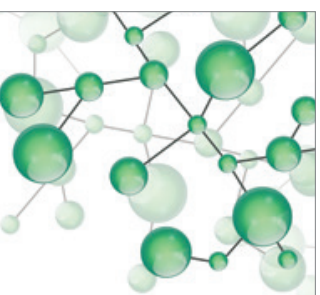

International Journal of

Inorganic Chemistry

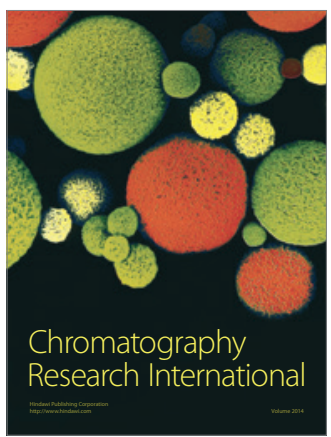

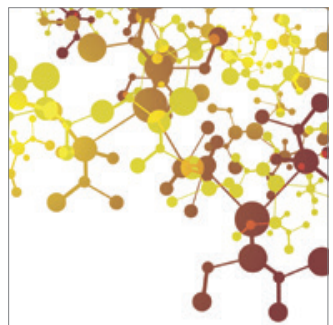

Applied Chemistry
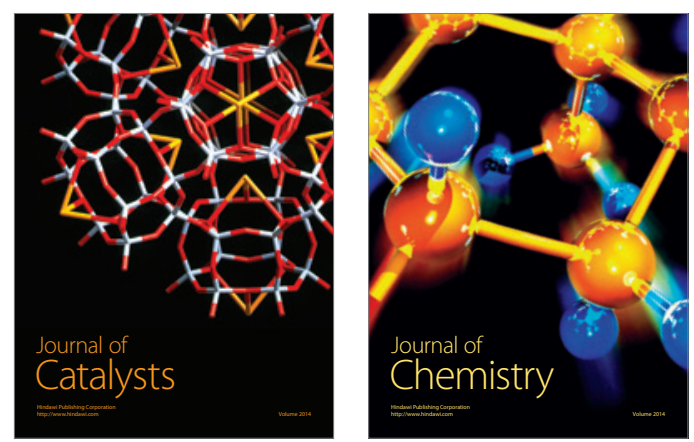
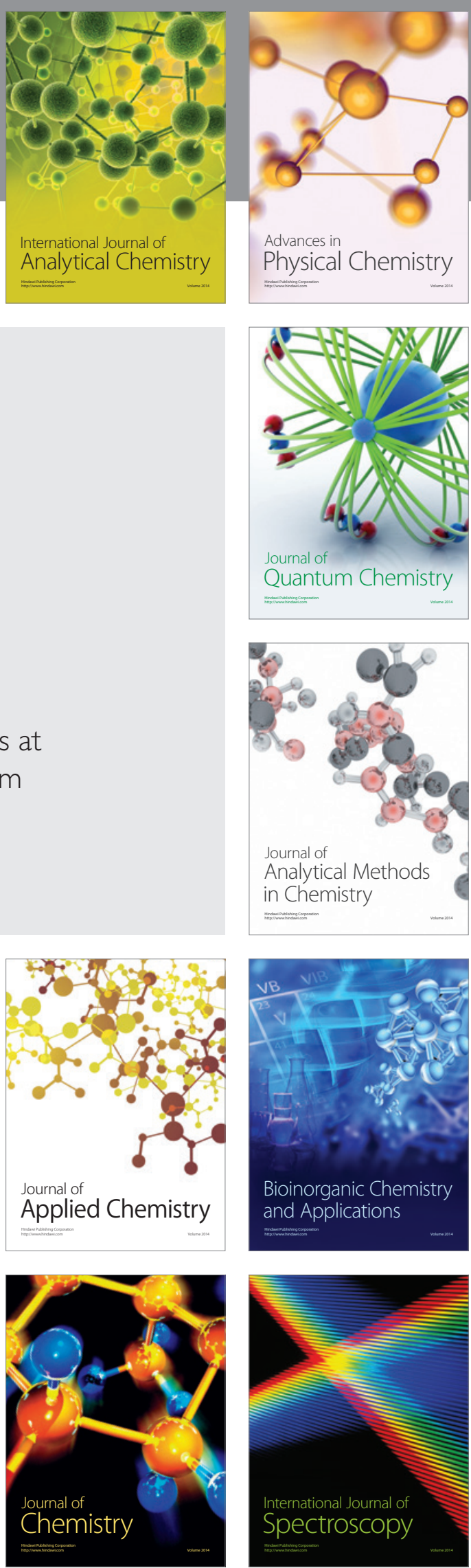